\title{
Creating positive outcomes through perceived investment in employee development: Evidence from Kuwait
}

\author{
Michel Zaitouni ${ }^{1}$
}

\begin{abstract}
Drawing on the human capital and social exchange theories, this article examines the effect of perceived investment in employee development on three work behavior outcomes: turnover intentions, organization citizenship behavior, and affective commitment. Data from a sample of 126 employees working at different hierarchical levels in three different organizations in Kuwait were collected and analyzed using hierarchical regression analysis. The results support previous studies and indicate that PIED is more related to OCB and affective commitment than turnover intentions.
\end{abstract}

Keywords: Effective commitment, $\mathrm{OCB}$, turnover intentions.

Available Online: 10-02-2016

This is an open access article under Creative Commons Attribution 4.0 License, 2015.

\subsection{INTRODUCTION}

It's of interest for all organizations to know that the outcome of any employee developmental activity is advancement potential, and that is exerting a high level of performance (De Pater, Van Vianen, Bechtoldt, \& Klehe, 2009a). By investing in employees' competencies, organizations would upgrade its employees' skills and knowledge required to adhere to competitive standards (Tsai and Tai 2003). Understanding the relationship between investment in employee development and individual outcomes has been one of the long-standing goals of behavioral research and has taken a cognitive approach. The specific nature of this relationship depends on the theoretical perspectives researchers have adopted when examining it.

On the one hand, many scholars have adopted the behavioral perspective of investment in employee development (Guest 2002; Edgar and Geare 2005; Muse and Stamper 2007). According to this perspective, the positive perception of employees toward their organization's willingness to increase their competencies is embedded within the context of social exchange theory (Blau 1964; Eisenberger, Huntington, Hutchison and Sowa 1986). Indeed, the employer-employee relationship is built on mutual

\footnotetext{
${ }^{1}$ College of Business Administration, Gulf University for Science and Technology (GUST)-Kuwait, Email: zaitouni.m@gust.edu.kw
} 
trust and obligation (Hom et al., 2009). Accordingly, employees will tend to believe that they are valued by their organization and reciprocate by working hard to achieve the organizational goals.

On the other hand, many researchers appear to be making the assumption that the stock of knowledge, skills, and abilities among employees provide economic value to the organization (McShane \& Von Glinow, 2013). Organizations focusing on the development of their employees more than their behavior invoke the human capital perspective of a firm (Becker, 1964; Lepak \& Snell, 1999). This perspective has generated a long debate among researchers on whether the human capital theory constitutes a competitive advantage or a huge risk for organizations. Some scholars have argued that high quality human capital can serve as a source of competitive advantage when investment in employee development increases organization's performance and realizes a return on their investments (Wright, McMahan, \& McWilliams, 1994; Bishop, 1997; Bartletl, 2001). Others realized that when key employees leave, they take with them some valuable knowledge that makes the organization effective. For that reason, organizations, within the human capital context, would not pay to invest in developing employees' general skills because such practice may increase employee turnover (Becker, 1965; Benson, Finegold and Mohrman, 2004).

The primary purpose of this study is to develop and empirically examine an integrative model of a direct linkage between perceived investment in employee development and individual outcomes such as turnover intentions, organizational citizenship behavior, and affective commitment. Drawing on the social exchange theory and the human capital theory, I intend to extend the existing employer-employee relationship approach to PIED by providing empirical evidence from the Kuwaiti industry and thereby enriching the existing literature with new theories about similarities and differences in perceived investment in employee development between the western and non-western contexts. First, I aim to study the effect of PIED on employee turnover intentions and the extent to which the developmental activities can increase or decrease an employee's intention to leave. Second, I intend to demonstrate how PIED will be seen differently across employees and can be defined and conceptualized as OCB. Third, this paper will try to offer an affective explanation of the PIED approach as a positive outcome of the relationship between employee development and organization commitment.

This article is organized as follows: First, I present the conceptual foundations of the research, beginning with a discussion about PIED and then its relationships with three different outcomes: Turnover intentions, OCB, and affective commitment. Second, I describe the methodology that was designed to test my hypothesized relationships based on a sample of 126 employees working in three different companies in Kuwait. Finally, I present the results of this study and discuss their theoretical and practical implications.

\subsection{THEORETICAL BACKGROUND AND HYPOTHESES}

\subsection{PERCEIVED INVESTMENT IN EMPLOYEE DEVELOPMENT}

Many researchers contended that investing in employee development is a motivational practice that leads to a positive attitudes and behavior of employees toward their organizations (Ichniowski et al., 1997; MacDuffie, 1995; Snell and Dean, 1992; Youndt et al., 1996). This motivational process creates an incentive for employees to behave reciprocally and in a positive way (Cropanzano \& Mitchell, 2005; Eisenberger et al. 2001). The employer-employee relation is rooted in the concept of the social exchange theory (Blau, 1964) where organizations provide employees with continuous learning to develop their skills and knowledge, and in return employees express loyalty and commitment to the organization.

Perceived investment in employee development can be defined as the employees' perceptions of the level of organization's commitment toward enriching their skills, knowledge, experiences, and abilities in order to prepare them for future positions, either within or outside the organization (Lee \& Bruvold, 2003; Rahman, 2012). Therefore, organization's commitment to employees' personal and professional 
growth and employees' beliefs that their organization values and recognizes their contribution can lead to various benefits such as greater productivity and financial performance, enhanced employee retention, positive motivation, and high commitment (Rothwell \& Kazanas, 1996; Wayne et al., 1997; Lee \& Bruvold, 2003; Shore, Tetrick, Lynch, \& Barksdale, 2006).

A central tenet in perceived investment in employee development is that the outcomes remain positive whether the process is formal or informal, or whether it is formally rewarded or contractually enforceable (Settoon, Bennett, \& Liden, 1996). This implies that organizations, in order to gain competitive advantage, should strive to create a culture that emphasizes a greater importance on upgrading employees' skills and knowledge, and therefore, shift to a learning organization to sustain a permanent employee development program (Malik et al., 2011).

\subsection{PERCEIVED INVESTMENT IN EMPLOYEE DEVELOPMENT AND TURNOVER INTENTIONS}

From the social exchange theory perspective (Blau 1964; Eisenberger et al., 1986), investing in employee development can create a positive mindset in employees toward the organization, resulting in a trusting and honoring employer-employee relationship (Benson et al., 2004; Kuvaas and Dysvik, 2009a; Lee \& Bruvold, 2003; Cropanzano \& Mitchell, 2005; Maurer and Lippstreu, 2008; Foong-ming, 2008). In return, employees will value this relationship which may enhance a stronger desire to stay with their current organization (Farrell and Rusbult, 1981; Sieben, 2007). Previous research has shown that the social exchange theory cannot solely explain the relationship between employee development and turnover intentions (George \& Bettenhausen, 1990; Huselid; 1995; Malik et al., 2011). According to these scholars, investment in employee development can be associated with many factors such as lower labor turnover, acquisition of non-portable skills, and a personal desire to maintain a valuable organization-employee relationship (McEnrue, 1989; Farrell and Rusbult, 1981).

According to Becker's human capital model (1993), the acquisition of general skills by employees will lead to an increase in turnover and non-transferable skills to a less impact on intentions to leave. Numerous scholars supported becker's human capital model. Frazis and Speltzer (2005) argued that employees who are provided with specific skills have fewer alternatives to quit the organization than those with general skills. Several studies have noticed that some organizations wait until employees are trained by other organizations to poach them and hire them to other companies (Lynch, 1991; Glance et al., 1997; Lynch \& Black, 1998). Thus, I hypothesize the following:

$\mathrm{H} 1$ : there will be a negative relationship between perceived investment in employee development and turnover intentions.

\subsection{PERCEIVED INVESTMENT IN EMPLOYEE DEVELOPMENT AND ORGANIZATIONAL CITIZENSHIP BEHAVIOR (OCB)}

It is well known among management researchers that organizations prefer employees who go beyond the required job duties (Barnard, 1938; Katz, 1964; Katz \& Kahn, 1978). This workplace behavior, referred to as organizational citizenship behavior, has received the attention of a great deal of scholars the last few decades (Bateman \& Organ, 1983; Smith, Organ, \& Near, 1983). One of the most commonly recognized definition is that of Organ (1988) who defined OCB as "individual behavior that is discretionary, not directly or explicitly recognized by the formal reward system, and in the aggregated promotes the effective functioning of the organization". Based on the "norm of reciprocity " of the social exchange theory, Shore et al. (2006) contended that investment in employee development creates feelings of employee obligation to reciprocate through behaviors that exceed their formal job requirements. According to Settoon, Bennett, and Liden (1996), what determines employees' behavior is the type of exchange relationships with organization and with supervisors. Development activities (such as developing a skill or capability) that is perceived to benefit both the organization and the supervisor more than the employee himself/herself is considered as OCB (Maurer, Pierce \& Sore, 2002). Similarly, employees who perceive those activities as beneficiary for them may reciprocate in performing 
duties not required formally by their job. The exchange relationship with organizations and supervisors leads to the conclusion of Organ (1990) which stated that the best theoretical explanation for OCB was the social exchange theory. Thus, I hypothesize the following:

$\mathrm{H}$ 2: there will be a positive relationship between perceived investment in employee development and organizational citizenship behavior (OCB).

\subsection{PERCEIVED INVESTMENT IN EMPLOYEE DEVELOPMENT AND AFFECTIVE COMMITMENT}

Several previous studies have investigated the relationship between employee development and organizational commitment (Steers, 1977; Bateman and Strasser, 1984; Morrow, 1993; Birdi et al., 1997; Ahmad \& Bakar, 2003; Bartlett \& Kang, 2004, Paul and Anantharaman, 2003; Tansky and Cohen, 2001). However, and within the human resource development literature, Mowday and colleagues (1979) defined organizational commitment as "the individual's identification with and involvement in a particular organization". Some authors emphasized the multifaceted dimensions of organizational commitment (Jaros, Jermier, Koehler, \& Sincich, 1993). Meyer and Allen (1991) proposed a three component model of affective, continuance and normative commitment. Accordingly, affective commitment refers to employees' strong emotional attachment to the organization and identification with its goals and values; Continuance commitment refers to the costs associated with employees' leaving the organization; and normative commitment refers to employees' feeling of obligation to remain in the organization.

Many scholars contended that this model has not received a universal support (Bergman, 2006; Chen \& Francesco, 2003; Cheng \& Stockdale, 2003). Within the framework of human resource development and its effect on organizational commitment, the affective construct has been extensively explored by numerous researchers as the only indicator of commitment (Kuvaas, 2006b; Sturges, Conway, Guest, \& Liefooghe, 2005). In this vein and from a social exchange perspectives, employees who perceive investment in their employment by their organizations will be emotionally committed to them and will reciprocate in increasing their productivity and commitment (Takeuchi, Lepak, Wang, \& Takeuchi, 2007; Balkin \& Richebé, 2007; Aguinis \& Kraiger, 2009). These studies suggest that organizations may enhance affective commitment by promoting awareness of training and development opportunities. Accordingly, numerous studies confirmed that as long as employees perceive investment in their development positively, a strong relationship with affective commitment arises (Bartlett 2001; Ahmad \& Bakar, 2003). Thus, I hypothesize the following:

H3: there will be a positive relationship between perceived investment in employee development and affective commitment.

\subsection{METHODOLOGY}

\subsection{PROCEDURES}

To test the relationship between PIED and employee outcomes a total of 200 paper-and-pencil questionnaires were administered to various levels of permanent employees in three different companies through their HR departments. Each form included on its cover page a letter to the participant explaining the purpose of the study. In order to achieve honest and non-predisposed results, employees participating in the survey were assured confidentiality; identification information was not required. In total, 126 employees responded which resulted in an overall usable response rate of $63.1 \%$ and a $36.9 \%$ non-usable response rate.

\subsection{SAMPLE PROPORTIONS}

The questionnaire participants were chosen based on a combination of cluster and simple random sampling methods. Three Kuwaiti companies were chosen: State Audit Bureau, Kuwait Institute for 
Scientific Research, and Partnerships technical Bureau, creating the cluster samples, and randomly chosen employees of each company were administered the survey.

Of the 126 participants, $54.8 \%$ were male and $45.2 \%$ were female. $73.8 \%$ of employees had more than 5 years of experience in their job and $83.1 \%$ of them had less than 10 years of experience in their current position. About $69.6 \%$ of employees held an undergraduate degree and the remaining ones held a master or a postgraduate degree. The population is relatively young since the majority of surveyed employees were less than 45.

\subsection{MEASURES}

The independent and dependent variables were measured using a five-point likert scale ranging from $1=$ strongly disagree to $5=$ strongly agree. The questionnaire included 29 items distributed as follows:

Independent variable-Perceived investment in employee development (PIED): which aimed at evaluating employees' views on organizations' continuous and long-term investment commitment in employee development was adapted from Lee \& Bruvold (2003). Seven items measured this variable; example items are, 'My organization stands out as an organization that is very focused on continuous development of the skill and abilities of its employees', as well as, 'I definitely think that my organization invests more heavily in employee development than comparable organizations'.

\subsection{DEPENDENT VARIABLES}

-Turnover intention ( $\mathrm{TI}$ ): turnover intentions were assessed by five items used by Kuvaas (2006a), such as: 'I will probably look for a new job next year', and 'I will likely actively look for a new job within the next three years'.

-Organization citizenship behavior (OCB): A seven-item scale validated by Van Dyne and LePine (1998) served to measure OCB. Examples of which include 'I volunteer to do things for my work group' and 'I attend functions that help my work group, even though they are beyond the formal requirements of my job'.

-Affective commitment (AC): Six previously used items from Meyer et al. (1993) were utilized to measure AC. Item models used include, 'This organization has a great deal of personal meaning for me' and 'I do not feel like "part of the family" at my organization'.

Gender, age, organizational tenure, positional tenure and educational level were included as control variables. Gender was measured as a dichotomous variable coded such that (1) was male and (2) was female; Age, grouped as such that (1) is 21-35 years, (2) is 36-55 years, and (3) is over 55 years; Years of work experience, grouped as such that (1) is 0-5 years, (2) is 6-10 years, and (3) is over 10 years of experience; Number of years in current position, grouped as such that (1) is 0-5 years, (2) is 6-10 years, and (3) is over 10 years of experience; Education level, categorized as such that (1) is high school education, (2) is having a diploma, (3) is having a graduate degree, (4) is having postgraduate degrees, and (5) as other educational levels achieved, which was left to be specified.

\subsection{RESULTS}

As shown in table I, the principal component analysis with varimax rotation was performed on all multiple scale items to determine item retention (e.g. Coyle-Shapiro et al., 2004). Although most of the scales have been used in prior research. Therefore, and in order to avoid confounded measures of the closelyrelated constructs, relatively stringent rules-of-thumb were applied, i.e. retention of items only with a strong loading of 0.40 or higher (Osborne and Costello, 2004), and a differential of 0.20 or higher between factors (Van Dyne et al., 1994). The principal component analysis revealed that one of the perceived supervisor support and one of the affective commitment items did not meet the 0.4 loading criterion. 
Table I: Principal component analysis with varimax rotation

\section{Perceived investment in employee development}

My organization invests heavily in employee development (for instance by way of training, programs, and career development)

My organization stands out as an organization that is very focused on $\quad .804$

continuous development of the skills and abilities of its employees

By investing time and money in employee development, my organization $\quad .870$

demonstrates that it actually invests in its employees

I'm confident that my organization will provide for the necessary training $\quad .847$

and development to solve any new tasks I may be given in the future

By way of practices such as developmental performance appraisal, counselling systems, competence development programs and leadership development programs, my

organization clearly demonstrates that it values development of the skills and abilities of its employees

I definitely think that my organization invests more heavily in employee development than comparable organizations

My organization is effective in meeting employees' requests for internal job transfers

\section{Turnover intentions}

I often think about quitting my present job

I may quit my present job during the next twelve months

I will probably look for a new job in the next year

I do not see many prospects for the future in this organization

I will likely actively look for a new job within the next three years

\section{Organization citizenship behavior}

I volunteer to do things for my work group

I help orient new employees in my work group

I attend functions that help my work group, even though they are beyond the formal requirements of my job

I assist others in my work group with their work for the benefit of the group

I get involved in order to benefit my work group

I help others in my work group learn about the work

I help others in my work group with their work responsibilities

\section{Affective commitment}

I would be very happy to spend the rest of my career in this organization

I really feel as if this organization's problems are my own

I do not feel like 'part of the family' at my organization

I do not feel 'emotionally attached' to this organization

I do not feel a strong sense of belonging to my organization

Eigenvalues

$\%$ of variance
PIED

TI OCB

.772

.844

.811

.712

Factor loadings less than 0.35 are not shown; underlined loadings are included in the final scales; PIED, perceived investment in employee development; TI, turnover intention; OCB, organizational citizenship behavior;, PSS, perceived supervisor support; AC, affective commitment

Means, standard deviations, and bivariate correlations are shown in table II.

Table II: Descriptive statistics, and correlations

$\begin{array}{llrrrrrrrrr} & \text { Means } & \text { SD } & \text { Age } & \text { Gender } & \text { Pos.Ten } & \text { Org.Ten Edu.Lev } & \text { PIED } & \text { AC } & \text { TI OCB } \\ \text { 1.Age } & 1.5476 & .49971 & 1 & & & & & & \\ \text { 2.Gender } & 1.4524 & .49971 & -.007 & 1 & & & & & \\ \text { 3.Pos.Tenure } & 2.1429 & .80711 & .082 & .672 * * & 1 & & & & \\ \text { 4.Org.Tenure } & 1.5645 & .76766 & .055 & .559 * * & .552^{* *} & 1 & & & \\ \text { 5.Edu.Level } & 3.2160 & .71374 & .143 & -.007 & .139 & .042 & 1 & & \\ \text { 6.PIED } & 3.0092 & .85515 & -.053 & .246 * * & .131 & .138 & -.084 & 1 & \\ \text { 7.AC } & 2.9080 & .56992 & -.032 & -.106 & -.121 & .006 & -.103 & .177 & 1\end{array}$




\begin{tabular}{|c|c|c|c|c|c|c|c|c|c|c|}
\hline 8.TI & 2.6733 & 1.02143 & .075 & $-.183^{*}$ & $-.264 * *$ & -.068 & .038 & $-.510 * *$ & .009 & 1 \\
\hline $9.0 C B$ & 3.9901 & .73201 & .066 & .138 & .169 & $.188 *$ & .059 & $.287^{* *}$ & .015 & $-.216 * *$ \\
\hline
\end{tabular}

Pos.Tenure = positional tenure; Org.Tenure = Organizational tenure; EduLevel = educational level; PIED = Perceived investment in employee development; $A C$ = affective commitment; $\mathrm{TI}=$ Turnover intention; OCB = Organization citizenship behavior.

Hierarchical regression analyses (in SPSS 20.0) were used to analyze the relations between perceived investment in employee development, perceived supervisor support and turnover intention, organization citizenship behavior and affective commitment (Table III). The control variables such as age, gender, organizational tenure, positional tenure and educational level were entered in the first step. Perceived investment in employee development was entered in the second step and was negatively but significantly related to turnover intention both before $(B=-.481, P<0.001)$ and after $(B=-.485, P<0.001)$ perceived supervisor support was included in the model. Moreover, perceived investment in employee development was positively and significantly related to both organization citizenship behavior $(B=.172$, $\mathrm{P}<0.01)$ and affective commitment $(\mathrm{B}=.175, \mathrm{P}<0.01)$.

Table III: Regression analysis predicting turnover intention, organization citizenship behavior and affective commitment.

\begin{tabular}{|c|c|c|c|c|c|c|}
\hline & \multicolumn{2}{|c|}{ Turnover intention } & \multicolumn{2}{|l|}{ OCB } & \multicolumn{2}{|c|}{ Affective commitment } \\
\hline & Step 1 & Step 2 & Step 1 & Step 2 & Step 1 & Step 2 \\
\hline Age & .045 & .053 & .076 & .072 & -.026 & -.038 \\
\hline gender & -.048 & .075 & .018 & -.034 & -.087 & -.150 \\
\hline Pos.Ten & $-.284^{*}$ & $-.328 * *$ & .079 & .102 & -.086 & -.062 \\
\hline Org.Ten & .132 & .142 & .109 & .102 & 109 & .102 \\
\hline Edu.Lev & .076 & .035 & -.013 & .002 & -.105 & -.088 \\
\hline PIED & & $-.481 * * *$ & & $.221 *$ & & $.218^{*}$ \\
\hline $\mathrm{R}$ & .069 & .218 & .039 & .046 & .033 & .044 \\
\hline square & & .287 & & .085 & & .077 \\
\hline change & & 30.630 & & 4.860 & & 4.774 \\
\hline $\begin{array}{l}\text { R } \\
\text { square }\end{array}$ & .069 & & .039 & & .033 & \\
\hline$F$ & 1.490 & & .781 & & .690 & \\
\hline $\begin{array}{l}* p<0.05 \\
\text { Standard } \\
\text { Pos.Ten } \\
\text { superviso } \\
\text { behavior. }\end{array}$ & $\begin{array}{l}* * p<0 \\
\text { ed regre } \\
\text { positior } \\
\text { suppor }\end{array}$ & $\begin{array}{l}* * p<0.00 \\
n \text { coefficier } \\
\text { enure, Org } \\
\text { D = perce }\end{array}$ & $\begin{array}{l}\text { anizatior } \\
\text { nent in }\end{array}$ & $\begin{array}{l}\text { enure, } E \\
\text { loyee d }\end{array}$ & $\begin{array}{l}\text { cationa } \\
\text { OCB = }\end{array}$ & $\begin{array}{l}\text { l, PSS = Perceived } \\
\text { nization citizenship }\end{array}$ \\
\hline
\end{tabular}

\subsection{DISCUSSION}

The main purpose of this study was to examine different alternative relationships between perceived investment in employee development and turnover intentions, organizational citizenship behavior and affective commitment. This was accomplished by an empirical investigation of the level of perception of investment in full-time Kuwaiti employee development, working at different hierarchical levels in three different companies in Kuwait.

The negative relationship between perceived investment in employee development and turnover intentions replicates the findings of Kalleberg and Rognes (2000) and Pfeffer and Sutton (2006). The latter propose that for organizations to avoid higher turnover intentions, they must provide all employees with opportunities to improve their skills and knowledge. These findings suggest that organizations able to elicit skills development programs that will maximally help employees to improve their competencies will be perceived as more credible and therefore, have direct impact in reducing turnover. 
Furthermore, this study examined a direct linkage between PIED and turnover intentions. Prior research suggested that this relationship could be mediated by many factors that may have a direct influence on turnover intentions. One of these factors is P-O fit. According to (Lauver and Kristof-Brown, 2001), the PO fit reduces employees' intentions to leave the organization. Employees prefer to stay with organizations that positively match their characteristics (Schneider, 1987; Van Vianen, 2000).

Another factor that may impact directly and mediate the relationship between PIED and turnover intentions is reward. Employees who ensure high levels of kills and abilities expect to be rewarded by their organization for the efforts they undertook to respond positively to training opportunities. Those employees are reluctant to leave their organization as they feel obliged to reciprocate the reward provided (Benson et al., 2004).

The findings of this study are also consistent with prior literature that examines the relationship between perceived investment in employee development and organizational citizenship behavior (OCB). A key point raised by the results of this study is that despite the positive relationship between the two variables, OCB should be viewed as a group phenomenon. According to Dysvik and Kuvaas (2008), little evidence confirms a direct linkage between PIED and OCB, therefore, this relationship needs to be assessed in relation to other sources affecting OCB such as employee intrinsic motivation. This finding suggests that employees who perceive positively their development opportunities would be intrinsically motivated and therefore increase their OCB. Although, intrinsic motivation can serve as an incentive for employees to put out efforts beyond what is expected of them as they feel obliged to reciprocate the positive perceived beneficiary of investment in their development. Intrinsically motivated employees are more aware of the importance of their development, and are more likely to be engaged in the work of their colleagues than employees with lower intrinsic motivation (Guay et al., 2000; Vansteenkiste et al., 2006).

The significant and positive relationship between perceived investment in employee development and affective commitment suggests that employees satisfied with development opportunities are more likely to have positive attitudes towards their organization and therefore build an emotional bond with it (Blau et ai, 2001; Tansky and Cohen, 2001). Ahmad \& Bakar (2003) found evidence of positive relationship between perceived training opportunity and affective commitment in a study conducted in a nonWestern society. It is of interest to mention here that the supervisor plays an important role in strengthening the relationship between employment development and affective commitment, especially in the Kuwaiti culture where personal relationships and individualized support from the supervisor are more valued than the system itself. Kuwait is considered a collectivistic society where supervisory styles are highly paternalistic (Tanure \& Duarte, 2005). Therefore, Kuwaiti employees who perceive their supervisor support for development programs positively report higher affective organizational commitment. Lee \& Bruvold (2003) found a positive linkage between PIED and employees' affective commitment and job satisfaction as well.

This study, like any other research, has some limitations that should be taken into consideration in the analysis of results. First, given data were obtained at one point in time means it is difficult to draw important conclusions about inference of causality. It is possible, for example, that affective commitment serves as antecedent of turnover intentions and therefore, influences positively employees with high intentions to leave the organization. To be more conscious about the causality inference on the relationship between the different variables of this study, longitudinal studies are needed. Second, the generalizability of findings could be a problem since this study is conducted in a specific country, Kuwait. Therefore, a question can be raised as to whether a more general employment development context would produce similar findings. Third, the fact that our data were obtained from cross-sectional selfcompleted survey, the possibility of common method variance is increased. In order to reduce the negative consequences associated with the use of self-report data, I tried to maintain confidentiality of responses and separate the scale items for the predictors and the criterion validity (Podsakoff et al., 2003) 
Future research should extend my efforts by considering specific areas of perceived investment in employee development with other variables. An interesting avenue for practitioners would be to investigate the mediating role of person-organization fit on the relationship between PIED and turnover intentions and how this relationship may differ across career stages. Such practice would enhance positively employees' commitment and their intention to stay within the organization. Another implication of this study is that in order for perceived investment in employee development to increase organizational citizenship behavior, this relationship must depend on employee level of intrinsic motivation. Future research might also suggest that employee development programs that provide employees with broadly marketable skills should be integrated with perceived supervisor support to increase affective commitment. Finally, I believe that this study should be replicated in different organizational settings and different perspectives taking into consideration the differences in culture between Kuwait and other cultural contexts.

\section{REFERENCES}

Aguinis, H., \& Kraiger, K. (2009). Benefits of training and development for individuals and teams, organizations, and society. Annual Review of Psychology, 60, 451-474

Ahmad, K. Z., \& Bakar, R. A. (2003). The Association between Training and Organizational Commitment among White Collar Workers in Malaysia. International Journal of Training and Development, 7(3), 166185.

Balkin, D. and N. Richebé: (2007), A Gift Exchange Perspective on Organizational Training', Human Resource Management Review 17(1), 52-62.

Barnard, C.I. (1938), The Functions of the Executive, Cambridge, MA: Harvard University Press.

Bartlett, K.R. (2001), 'The Relationship Between Training and Organizational Commitment: A Study in the Health Care Field,' Human Resource Development Quarterly, 12, 335-352.

Bartlett, K. R., \& Kang, D. (2004). Training and organisational commitment among nurses following industry and organizational change in New Zealand and the United States. Human Resource Development International, 7 (4), 423-440.

Bateman, T. \& Strasser, S. (1984). "A longitudinal analysis of the antecedents of organizational commitment". Academy of Management Journal, 21, 95-112.

Bateman, T.S. and Organ, D.W., (1983). Job satisfaction and the good soldier: the relationship between affect and citizenship. Academy of Management Journal, 26, 587-595.

Becker, G. S. (1964). Human capital: A theoretical and empirical analysis. Chicago: University of Chicago Press.

Becker, G. 1965. Human capital. Chicago: University of Chicago Press.

Becker, G. S. (1993). Human Capital: A Theoretical and Empirical Analysis with Special Reference to Education (3rd Ed.). Chicago: University of Chicago Press.

Benson, G.S., Finegold, D., and Mohrman, S.A. (2004), 'You Paid for the Skills, Now Keep Them: Tuition Reimbursement and Voluntary Turnover,' Academy of Management Journal, 47, 315-331.

Bergman, M. E. (2006). The relationship between affective and normative commitment: Review and research agenda. Journal of Organizational Behavior, 27, 645-663.

Birdi, K., C. Allan, and P. Warr. (1997). Correlates of perceived outcomes of four types of employee development activity, Journal of Applied Psychology 82(6) 845-857.

Bishop, J. (1997). What we know about employer-provided training: A review of the literature. Research in Labor Economics, 16: 19-87.

Blau, G., Merriman, K., Tatum, D., \& Rudman, S. (2001). Antecedents and consequences of basic versus career enrichment benefit satisfaction. Journal of Organizational Behavior, 22, 669688.

Blau, P. (1964), Exchange and Power in Social Life, New York: Wiley.

Chen, Z. X. \& Francesco, A. M. (2003). The relationship between the three components of commitment and employee performance in China. Journal of Vocational Behavior, 62: 490-510.

Cheng, Y. \& Stockdale, M. S. (2003). The validity of the three-component model of organizational commitment in a Chinese context. Journal of Vocational Behavior, 62: 456-489. 
Coyle-Shapiro, Jacqueline A-M. and Neuman, Joel H. (2004) The psychological contract and individual differences: the role of exchange and creditor ideologies. Journal of Vocational Behavior, 64 (1). 150164

Cropanzano, R., \& Mitchell, M. (2005). Social exchange theory: An interdisciplinary review. Journal of Management, 31(6), 874.

De Pater, I. E., Van Vianen, A. E. M., Bechtoldt, M. N., \& Klehe, U. (2009a). Employees' challenging job experiences and supervisors' evaluations of promotability. Personnel Psychology, 62: 297-325.

Dysvik, A \& Kuvaas, B., (2008), "The relationship between perceived training opportunities, work motivation and employee outcomes", International Journal of Training and Development, vol: 12, pp:138-157.

Edgar, F. \& Geare, A. (2005). HRM practice and employee attitudes: Different measures - different results. Personnel Review, 34(5), 534-549.

Eisenberger, R., Armeli, S., Rexwinkel, B., Lynch, P. D., \& Rhoades, L. (2001). Reciprocation of perceived organizational support. Journal of Applied Psychology, 86(1), 42-51.

Eisenberger, R., Huntington, R., Hutchinson, S. and Sowa, D. (1986), "Perceived organizational support", Journal of Applied Psychology, Vol. 71, pp. 500-7.

Farrell, D., \& Rusbult, C. E. (1981). Exchange variables as predictors of job satisfaction, job commitment, and turnover: The impact of rewards, costs, alternatives, and investments. Organizational Behavior and Human Performance, 27, 78-95.

Foong-ming, T. (2008), "Linking career development practices to turnover intention: the mediator of perceived organizational support", Journal of Business and Public Affairs, Vol. 2 No. 1, pp. 1-20.

Frazis, H. J., and Speltzer, J. R. (2005). Worker training: What we've learned from the NLSY79. Monthly Labor Review, 128(2): 48-58.

George, J. M., \& Bettenhausen, K. (1990). Understanding prosocial behavior, sales performance, and turnover: A group-level analysis in a service context. Journal of Applied Psychology, 75: 698-709.

Glance, N.S., Hogg, T., and Huberman, B.A. (1997). Training and turnover in the evolution of organizations. Organization Science, 8(1): 84-96.

Guay, F., Vallerand, R. J., \& Blanchard, C. (2000). On the assessment of situational intrinsic and extrinsic motivation: The Situational Motivation Scale (SIMS). Motivation and Emotion, 24, 175-213.

Guest, D., \& Conway, R. (2002). Communicating the psychological contract: An employer perspective. Human Resource Management Journal, 12 (2): 22-38.

Hom, P. W., Tsui, A., Lee, T., Fu, P., Wu, J. B., Zhang, Y., \& Li, L. (2009). Explaining employment relationships with social exchange and job embeddedness. Journal of Applied Psychology, 94: 277297.

Huselid, M. A. (1995). The impact of human resource management practices on turnover, productivity, and corporate financial performance. Academy of Management Journal, 38: 635-672.

Ichniowski, C., Shaw, K., \& Prennushi, G. (1997). The effects of human resource management practices on productivity. American Economic Review, 87, 291-313.

Jaros, S. J., Jermier, J. M., Koehler, J. W., \& Sincich, T. (1993). Effects of continuance, affective, and moral commitment on the withdrawal process: An evaluation of eight structural equation models. Academy of Management Journal, 36(5), 951-995.

Kalleberg AL, Rognes J (2000). Employment relations in Norway: Some dimensions and correlates. Journal of Organizational Behavior., 21(3): 315-335.

Katz, D. (1964). The Motivational Basis of Organizational Behavior. Behavioral Science, 9, 131-146.

Katz, D., \& Kahn, R. L. (1978). The Social Psychology of Organizations, $2^{\text {nd }}$ ed.. New York: John Wiley \& Sons.

Kuvaas, B., and Dysvik, A. (2009a), 'Perceived Investment in Employee Development, Intrinsic Motivation, and Work Performance,' Human Resource Management Journal, 19, 217-236.

Kuvaas, B. (2006a), 'Performance appraisal satisfaction and employee outcomes: mediating and moderating roles of work motivation', International Journal of Human Resource Management, 17, 3, 504-22.

Kuvaas, B. (2006b), 'Work performance, affective commitment, and work motivation: the roles of pay administration and pay level', Journal of Organizational Behavior, 27, 3, 365-85.

Lauver, K., \& Kristof-Brown, A. (2001). Distinguishing between employees' perceptions of person-job and person-organization fit. Journal of Vocational Behavior, 59(3), 454-470. 
Lee, C.H., and Bruvold, N.T. (2003), 'Creating Value for Employees: Investment in Employee Development,' International Journal of Human Resource Management, 14, 981-1000.

Lepak, D. P., \& Snell, S. A. (1999). The human resource architecture: Toward a theory of human capital allocation and development. Academy of Management Review, 24: 31-48.

Lynch, L. M. (1991), "The Role of Off-the Job vs. On-the-Job Training for the Mobility of Young Women Workers," American Economic Review 81, 151-156.

Lynch, L. M., \& Black, S. E. (1998). Beyond the incidence of employer-provided training. Industrial and Labor Relations Review, 52(1): 64-81.

MacDuffie, John Paul. (1995). "Human Resource Bundles and Manufacturing Performance: Organizational Logic and Flexible Production Systems in the World Auto Industry," Industrial and Labor Relations, 48(2), January, 197-221.

Malik, O.F., Abbas, Q., Kiyani, T.M., Malik, K.U.R. and Waheed, A. (2011), "Perceived investment in employee development and turnover intention: a social exchange perspective", African Journal of Business Management, Vol. 5 No. 5, pp. 1904-1914.

Maurer, T.J. and Lippstreu, M. (2008), "Who will be committed to an organization that provides support for employee development?", Journal of Management Development, Vol. 27 No. 3, pp. 328-347.

Maurer, T., Pierce, H.,\&Shore, L. (2002). Perceived beneficiary of employee development activity: Athreedimensional social exchange model. Academy of Management Review, 27(3), 432-444.

McEnrue, M. P. (1989). Self-development as a career management strategy. Journal of Vocational Behavior, 34: 57-68

McShane, S. \& Von Glinow, M. (2013). M Organizational Behavior. New York, New York: McGraw-Hill/Irwin.

Meyer, J.P, Allen, N.J. \& Smith, C.A. (1993). Commitment to organizations and occupations: extension and test of a three component conceptualization. Journal of Applied Psychology, 78 (4), 538-551.

Meyer, J.P. \& Allen, N.J. (1991). A Tree-component conceptualitazation of organizational commitment. Human Resource Management Review, 1, 61-89.

Morrow, P.C., (1993), “The Theory and Measurement of Work Commitment”, JAI Pres, Greenwich.

Mowday, R., Steers, R., and Porter, L. (1979). The measurement of organizational commitment. Journal of Vocational Behavior, 14, 224-247.

Muse, L. A., \& Stamper, C. L. (2007). Perceived Organizational Support: Evidence for a Mediated Associadon with Work Performance. Journal of Managerial Issues, 14(4), 517-535.

Organ, D. (1990). The motivational basis of organizational citizenship behavior. In B. M. Staw \& L. L. Cummings (Eds.), Research in organizational behavior, Vol. 12, pp. 43-72

Organ, D. W. 1988. Organizational citizenship behavior: The good soldier syndrome. Lexington, MA: Lexington Books.

Osborne, J. W., \& Costello, A. B. (2004). Sample size and subject to item ratio in principal components analysis. Practical Assessment, Research \& Evaluation, 9(11). Retrieved July 1, 2008 from http://PAREonline.net/getvn.asp?v=9\&n=11.

Paul, A. K., Anantharaman, R. N., (2003). Impact of people management practices on organizational performance: analysis of a causal model, International Journal of Human Resource Management, 14 (7): 1246-1266.

Pfeffer and Sutton (2006). "Evidence-based management", Harvard Business review, January, pp 62-74.

Podsakoff, P. M., MacKenzie, S. B., Lee, J.-Y., \& Podsakoff, N. P. (2003). Common method biases in behavioral research: A critical review of the literature and recommended remedies. Journal of Applied Psychology, 88, 879-903.

Rahman, W. (2012), Attitudinal and Behavioral Outcomes Link with Employee Development in the Context of Performace Appraisal: Empirical Evidence from Public Universities in Khyber| Pakhtunkwa, Lambert Academic Publishing, Pakistan.

Rothwell, W. J. (1996). ASTD Models for human performance improvement, roles, competencies, and outputs, ASTD Publications Dept., 1640 King Street, Box 1443, Alexandra, Virginia 22313.

Schneider, B. (1987). The people make the place. Personnel Psychology, 40, 437-453.

Settoon, R., Bennett, N., \& Liden, R. (1996). Social exchange in organizations: Perceived organizational support, leader-member exchange, and employee reciprocity. Journal of Applied Psychology, 81(3), 219-227. 
Shore, L. M., Tetrick, L. E., Lynch, P. \& Barksdale, K. (2006). Social and economic exchange: Construct development and validation. Journal of Applied Social Psychology, 36, 837-867.

Sieben, I. (2007), "Does training trigger turnover - or not? The impact of formal training on graduates' job search behaviour", Work, Employment \& Society, Vol. 21, pp. 397-416.

Smith, C. A., Organ, D. W., \& Near, J. P. (1983). Organizational citizenship behavior: Its nature and antecedents. Journal of Applied Psychology, 68: 655-663.

Snell, S., \& Dean, J.W., Jr. (1992). Integrated Manufacturing and Human Resource Management: A Human Capital Perspective. Academy of Management Journal, 35, 467-504.

Steers, R.M. (1977). Antecedents and outcomes of organizational commitment. Administrative Science Quarterly, 22, 46-56.

Sturges, J, Conway, N, Guest, D \& Liefooghe, A (2005), 'Managing the career deal: The psychological contract as a framework for understanding career management, organizational commitment and work behavior' Journal of organizational behavior, vol 26, no. 7, pp. 821-838.

Takeuchi, R., Lepak, D. P., Wang, H., \& Takeuchi, K. (2007). An empirical examination of the mechanisms mediating between high performance work systems and the performance of Japanese organizations. Journal of Applied Psychology, 92: 1069-1083.

Tansky, J.W., \& Cohen, D.J. (2001). The relationship between organizational support, employee development, and organizational commitment: an empirical study. Human Resource Development Quarterly, 12, 285-300.

Tanure, B. \& Duarte, R. G. (2005). Leveraging competitiveness upon national culture traits: The management of people in Brazilian companies. International Journal of Human Resource Management, 16(12), 2201-2217.

Tsai, W.-C., and Tai, W.-T. (2003), 'Perceived Importance as a Mediator of the Relationship between Training Assignment and Training Motivation,' Personnel Review, 32, 151-163.

Van Dyne, L. and LePine, J. A. (1998), 'Helping and voice extra-role behaviors: evidence of construct and predictive validity', Academy of Management Journal, 41, 1, 108-19.

Van Dyne, L., Graham, J., \& Dienesch, R. M. (1994). Organizational citizenship behavior: construct redefinition, measurement, and validation. Academy of Management Journal, 37: 765-802.

Vansteenkiste, M., Lens, W., \& Deci, E. L. (2006). Intrinsic vs. extrinsic goal contents in self-determination theory: another look at the quality of academic motivation. Educational Psychologist, 41, 19-31.

Van Vianen, A.E.M. (2000) 'Person-Organization Fit: The Match between Newcomers' and Recruiters' Preferences for Organizational Cultures', Personnel Psychology, 53(1): 1-32.

Wayne, S.J., Shore, M., and Liden, R.C. (1997), 'Perceived Organizational Support and Leader-Member Exchange: A Social Exchange Perspective,' Academy of Management Journal, 40, 82-111.

Wright, P. M., McMahan, G. C., \& McWilliams, A. (1994). Human resources and sustained competitive advantage: A resource-based perspective. International Journal of Human Resource Management, 5 (2), 301-326.

Youndt, M. A., Snell, S. A., Dean, J. W., Jr, \& Lepak, D. P. (1996). Human Resource Management, Manufacturing Strategy, and Firm Performance. Academy of Management Journal, 39, 836-866. 